\title{
IMMUNOGENETIC PREDICTORS OF THE DEVELOPMENT OF BRONCHIAL OBSTRUCTION DURING ACUTE BRONCHITIS IN INFANTS
}

DOI: 10.36740/WLek202002121

\author{
Alexandr E. Abaturov, Olena 0. Rusakova \\ STATE INSTITUTION “DNIPROPETROVSK MEDICAL ACADEMY OF THE MINISTRY OF HEALTH OF UKRAINE”, DNIPRO, UKRAINE
}

\begin{abstract}
The aim: To determine the most informative immunological and molecular genetic factors which reflect the characteristics of the inflammatory process and make it possible to predict the development of bronchial obstruction during acute bronchitis in infants.

Materials and methods: 120 children aged from 6 months to 3 years old with acute bronchitis were examined. We determined NF-kB expression level in peripheral blood lymphocytes by flow cytometry method, the serum concentrations of interferon- $\gamma$, interleukins 4,12 and 13 by ELISA, total IgE serum level by ECLIA and calculated the relative risk (RR) for each of these parameters.

Results: The risk of bronchial obstruction development was high when the relative number of lymphocytes expressing NF- $\mathrm{KB}$ was under $49.8 \%(\mathrm{RR}=3.27,95 \% \mathrm{Cl}=2.09-4.92)$. IL-12 serum concentration from $41.35 \mathrm{pg} / \mathrm{ml}$ to $173.06 \mathrm{pg} / \mathrm{ml}(\mathrm{RR}=5.35,95 \% \mathrm{Cl}=2.82-9.15)$ and IL-13 serum concentration from $4.06 \mathrm{pg} / \mathrm{ml}$ to $6.71 \mathrm{pg} / \mathrm{ml}$ (RR=4.0, 95\% $\mathrm{Cl}=2.39-6.41)$ were early predictors of the appearance of wheezing during the disease. The probability of the development of bronchial obstruction was low when the relative number of lymphocytes expressing NF-KB was above $49.8 \%$ ( $R R=0.40,95 \% \mathrm{Cl}=0.28-0.62)$. NF- $\mathrm{kB}$ expression level above 0.91 Units ( $\mathrm{RR}=0.20,95 \% \mathrm{Cl}=0.11-0.39$ ), serum concentrations of IFN- $\gamma$ above $9.83 \mathrm{pg} / \mathrm{ml}(\mathrm{RR}=0.50,95 \% \mathrm{Cl}=0.31-0.81), \mathrm{IL}-12$ above $173.06 \mathrm{pg} / \mathrm{ml}(\mathrm{RR}=0.49,95 \% \mathrm{Cl}=0.30-0.82), \mathrm{IL}-13$ above $6.71 \mathrm{pg} / \mathrm{ml}(\mathrm{RR}=0.40,95 \%$ $\mathrm{Cl}=0.22-0.72)$ reduced the probability of the appearance of wheezing significantly.

Conclusions: The development of bronchial obstruction during acute bronchitis in infants is associated with the relatively low NF-KB and IL- 12 levels, imbalance in IFN- $\gamma$ and IL-13 production.
\end{abstract}

KEY WORDS: acute bronchitis, bronchial obstruction, NF-KB transcription factor, cytokines, immunoglobulin E, infants

Wiad Lek. 2020;73(2):316-320

\section{INTRODUCTION}

Respiratory diseases make up $68.2 \%$ in the structure of general disease incidence of children in Ukraine [1]. Acute bronchitis is one of the most common diseases of the lower respiratory tract among children. It is recorded in early childhood more often than in other periods. The annual incidence of acute bronchitis is 75 cases per 1000 children aged from 0 to 12 months and 250 cases per 1000 children aged from 1 to 3 years old [2]. Every third infant wheezes during an episode of viral bronchial tree infection [3]. The development of bronchial obstruction during acute bronchitis is determined by the anatomical and physiological features of the respiratory system, the properties of the etiological agent, the nature and intensity of the inflammation, which are the result of the interaction of genetic, biomedical, social and hygienic factors. The tendency for the development of bronchial obstruction during acute bronchitis in infants is associated with perinatal pathology, artificial feeding, hereditary predisposition to allergic diseases, bronchial hyperreactivity, passive smoking, physical growth and development disorders, deficiency diseases, frequent respiratory viral infections [4-10].

\section{THE AIM}

The aim of our study was to determine the most informative immunological and molecular genetic factors which reflect the characteristics of the inflammatory process and make it possible to predict the development of bronchial obstruction during acute bronchitis in infants.

\section{MATERIALS AND METHODS}

We have examined 120 children aged from 6 months to 3 years old with diagnosis of acute bronchitis treated in in-patient department of the municipal institution "Dnipro city clinical hospital №1", Dnipro city, Ukraine. There were 80 patients $(66.7 \%)$ among them who had the bronchial obstruction developed.

The scientific research was carried out in accordance with the basic GCP regulations and the Helsinki Declaration, approved by the local Bioethics Commission. The parents or the guardians of the patients were informed about the study and gave their consent to taking part in it.

Clinical examination of the patients was the main research method. Laboratory and instrumental methods used to verify the clinical diagnosis were regulated by 


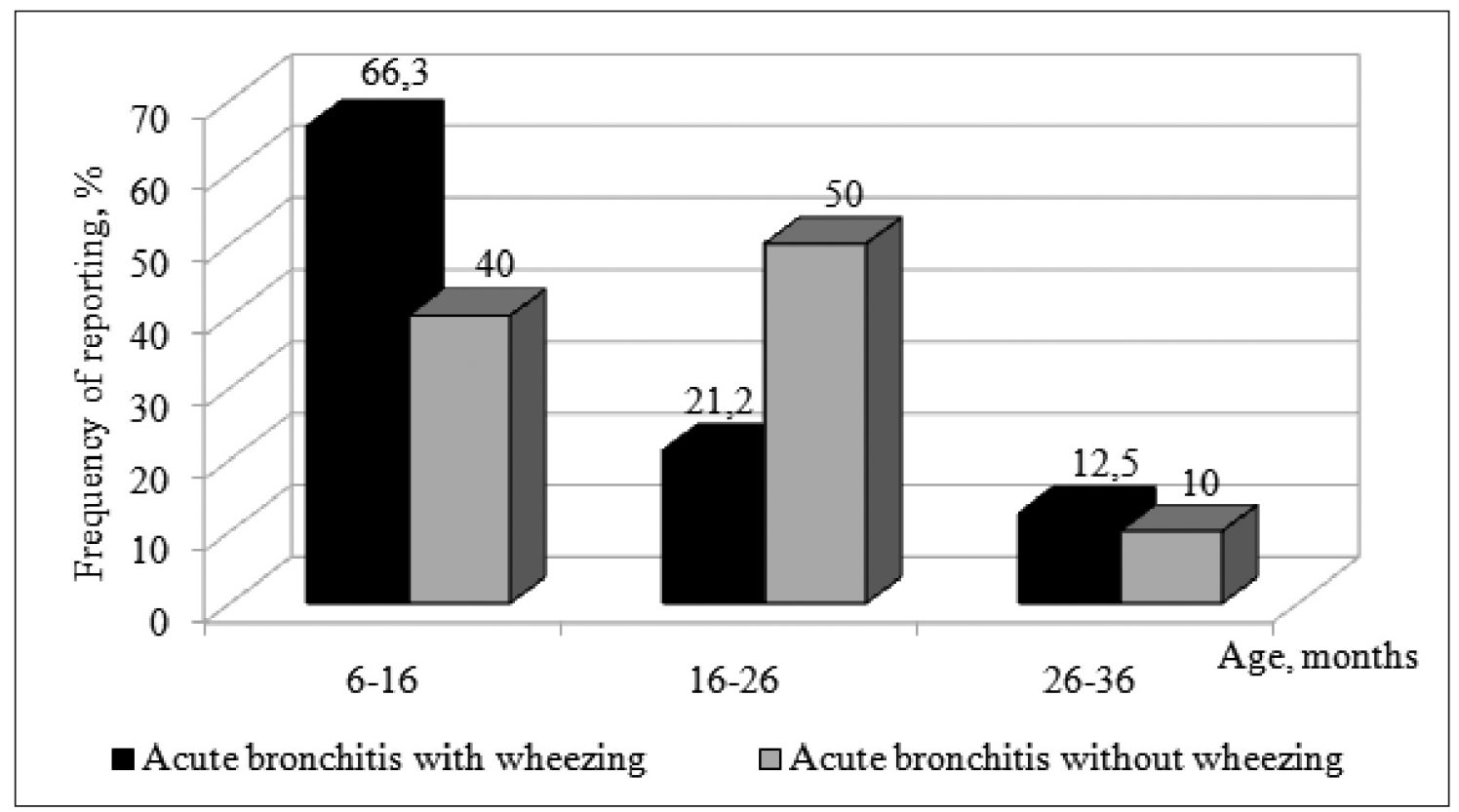

Figure 1. Age structure of acute bronchitis in infants

the current standards of medical care for children in the specialty "Pediatric pulmonology".

Also we determined NF- $\kappa \mathrm{B}$ expression level in peripheral blood lymphocytes. Monoclonal antibodies against the p65 subunits of the NF- $\kappa$ B molecules (BD Biosciences Pharmingen, USA) were used for this purpose. The samples were analyzed by EPICS XL-MCL Flow Cytometer (Beckman Coulter, USA) using System II ${ }^{\mathrm{TM}}$ software. The study has been performed at the Scientific Research Institute of the Ukrainian Medical Stomatological Academy, Poltava, Ukraine.

The serum concentrations of interferon- $\gamma$ (IFN- $\gamma$ ), interleukins (IL) 4, 12 and 13 were determined by ELISA using appropriate monoclonal antibodies of "Human IFN- $\gamma$ Platinum ELISA BMS228” (eBioscience, USA), "A-8754 IL-4-ELISA-BEST" ("VECTOR-BEST", Russia), "Human IL-12 (p40/p70) ELISA Kit KHC0121” (Invitrogen, USA), "Human IL-13 Platinum ELISA BMS231/3" (eBioscience, USA) kits. Total immunoglobulin E (IgE) serum level was determined by ECLIA using "Elecsys IgE" REF 04827031 190" reagent kit (Roche Diagnostics, Switzerland). The immunological studies have been performed at the diagnostic and treatment center of the Medical Academy, Dnipro, Ukraine.

Statistical analysis of the research results was carried out by a personal computer using the software package "STATISTICA 6.1" (serial number - AGAR909E415822FA). Parametric and non-parametric statistical methods were used. We processed 153 clinical, anamnestic, immunological and molecular genetic parameters, calculated the relative risk (RR), the confidence interval (95\% CI) for each of them and singled out the most informative predictors of bronchial obstruction in infants. The differences between the compared parameters were considered as statistically significant when $\mathrm{p} \leq 0.05$.

\section{RESULTS AND DISCUSSION}

There were 62 boys (77.5\%) and 18 girls (22.5\%) among the patients who wheezed during acute bronchitis. They were divided by age in the following way: children aged from 6 to 12 months - 50\% (40 cases), children aged from 1 to 2 years old $-36.2 \%$ ( 29 cases), children aged from 2 to 3 years old $-13.8 \%$ (11 cases). The average age of the patients was $14.1 \pm 0.9$ months.

The group of infants, suffering from acute bronchitis without wheezing, included 22 boys (55\%) and 18 girls (45\%). There were 11 children aged from 6 to 12 months (27.5\%), 24 children aged from 1 to 2 years old (60\%), 5 children aged from 2 to 3 years old (12.5\%) in the group. The average age of the patients was $16.9 \pm 1.1$ months.

Age structure analysis of acute bronchitis cases in the infants (Fig. 1) showed that the maximum risk for the development of bronchial obstruction during the disease was observed in children aged from 6 to 16 months $(\mathrm{RR}=1.46,95 \% \mathrm{CI}=1.09$ 1.94) and to a certain extent it could be explained by the anatomical and physiological features [11, 12].

Regarding to sex assignment, the male gender was a risk factor of bronchial obstruction $(\mathrm{RR}=1.48,95 \% \mathrm{CI}=1.04$ 2.10 ), while the female gender was a protector against its development $(\mathrm{RR}=0.48,95 \% \mathrm{CI}=0.31-0.74)$. The causes of this phenomenon are unclear, although it is reported, that the lungs of newborn boys are smaller than the same ones of newborn girls [13].

We have singled out the most informative clinical and anamnestic predictors of the development of bronchial obstruction during the infection process in the infants. Thus, wheezing in the child suffering from acute bronchitis was associated with the age of his father. The relative risk of the development of bronchial obstruction increased in children whose fathers were younger than 28 years old $(R R=1.53,95 \%$ $\mathrm{CI}=1.16-1.99)$ and older than 38 years old $(\mathrm{RR}=2.08,95 \%$ 
$\mathrm{CI}=1.60-2.59)$. At the same time, the age between 28 and 38 years old acted as a protector factor $(\mathrm{RR}=0.47,95 \% \mathrm{CI}=0.29$ $0.74)$. Interestingly enough, the maternal age did not affect the probability of bronchial obstruction development.

Wheezing was associated with birth from repeated (III-V) pregnancies $(\mathrm{RR}=1.67,95 \% \mathrm{CI}=1.31-1.89)$, antibiotic treatment during the pregnancy ( $\mathrm{RR}=1.75,95 \% \mathrm{CI}=1.36-1.98)$ and preterm birth $(\mathrm{RR}=1.67,95 \% \mathrm{CI}=1.21-1.82)$. The high risk of bronchial obstruction development was observed in children with intrauterine growth restriction $(\mathrm{RR}=2.92,95 \%$ $\mathrm{CI}=2.02-4.15)$. However, anemia during the pregnancy practically excluded the infant's wheezing $(\mathrm{RR}=0.29,95 \% \mathrm{CI}=0.17$ 0.92). The risk for the development of bronchial obstruction was significantly increased in cases of early cessation of breastfeeding $(\mathrm{RR}=2.23,95 \% \mathrm{CI}=1.64-3.00)$. At the same time, breast milk feeding for more than 15 months was a protector against wheezing $(\mathrm{RR}=0.29,95 \% \mathrm{CI}=0.17-0.92)$. Hereditary risk of atopy $(\mathrm{RR}=2.23,95 \% \mathrm{CI}=1.52-3.23)$ and passive smoking $(\mathrm{RR}=3.77,95 \% \mathrm{CI}=2.23-5.97)$ significantly contributed to the development of bronchial obstruction in infants. Most of our patients $(85 \%)$ had had acute respiratory tract infections (ARTI) before. We determined the maximum risk for wheezing in children who had got ARTI firstly at the age between 8 and 15 months $(\mathrm{RR}=1.70,95 \% \mathrm{CI}=1.25-1.98)$. Recurrent respiratory infections significantly increased the probability of the bronchial obstruction development $(\mathrm{RR}=1.88,95 \%$ $\mathrm{CI}=1.34-2.45)$. The mention of acute bronchitis with wheezing in the anamnesis $(\mathrm{RR}=5.35,95 \% \mathrm{CI}=2.82-9.15)$ and its tendency to be repeated were weighty predictors of the development of recurrent bronchial obstruction $(\mathrm{RR}=4.0,95 \%$ $\mathrm{CI}=2.54-6.53$ ). Also we determined connections between wheezing and hypovitaminosis $\mathrm{D}(\mathrm{RR}=1.46,95 \% \mathrm{CI}=1.01$ 1.64), perinatal brain damage ( $\mathrm{RR}=1.87,95 \% \mathrm{CI}=1.27-2.04)$, obesity $(\mathrm{RR}=4.58,95 \% \mathrm{CI}=2.57-7.30)$. Our results coincide with other researchers' data $[4,7,8,14-17]$.

All our patients fell ill acutely. Cough and fever were the first symptoms of the disease. The children, whose body temperature at the beginning of the disease was under $37.7^{\circ} \mathrm{C}$, made up the group of maximum risk for the development of bronchial obstruction $(\mathrm{RR}=7.50$, $95 \% \mathrm{CI}=3.29-17.06)$. A fever above $38.9{ }^{\circ} \mathrm{C}$ significantly reduced the probability of the appearance of wheezing $(\mathrm{RR}=0.32,95 \% \mathrm{CI}=0.16-0.65)$. Mild intoxication syndrome $(\mathrm{RR}=5.83,95 \% \mathrm{CI}=2.95-11.49)$, its continuance under 3 days $(\mathrm{RR}=3.33,95 \% \mathrm{CI}=2.01-5.35)$ and free nasal breathing ( $\mathrm{RR}=3.75,95 \% \mathrm{CI}=2.18-5.61)$ were the early clinical predictors of bronchial obstruction. The absence of peripheral microlymphadenopathy syndrome reduced the likelihood of wheezing during acute bronchitis in infants ( $R R=0.42,95 \% \mathrm{CI}=0.24-0.76)$. The onset of the disease was characterized by inflammatory changes in peripheral blood regardless of the course of acute bronchitis.

\section{EXPRESSION OF NF-KB TRANSCRIPTION FACTOR IN INFANTS WITH ACUTE BRONCHITIS}

The expression level of NF- $\kappa \mathrm{B}$ transcription factor reached $0.71 \pm 0.02$ Units in the children suffering from acute bronchitis with wheezing and $0.70 \pm 0.03$ Units in the children suffering from acute bronchitis without respiratory disorders $(p>0.05)$. The relative number of lymphocytes expressing NF- $\kappa \mathrm{B}$ transcription factor also did not depend on the course of the disease (table 1). The results we have obtained probably indicate the similarity of the molecular genetic characteristics of the inflammatory process in infectious affection of the bronchial mucous membrane, which coincides with other researchers' data [18].

The risk of bronchial obstruction development was high when the relative number of lymphocytes expressing NF$\kappa \mathrm{B}$ transcription factor was under $49.8 \%(\mathrm{RR}=3.27,95 \%$ $\mathrm{CI}=2.09-4.92$ ), and the risk was low when the relative number of lymphocytes expressing NF- $\kappa B$ was above $49.8 \%$ $(\mathrm{RR}=0.40,95 \% \mathrm{CI}=0.28-0.62)$. The expression level of the nuclear factor $\kappa \mathrm{B}$ above 0.91 Units was a protector of the development of bronchial obstruction ( $R R=0.20,95 \%$ $\mathrm{CI}=0.11-0.39$ ). The obtained data can be explained by the direct effect of NF- $\kappa B$ transcription factor on $\mathrm{Th}_{1}$-associated cytokines production, in particular, on the production of IFN- $\gamma$ [18-20].

\section{CYTOKINE PROFILE AND TOTAL IgE IN INFANTS WITH ACUTE BRONCHITIS}

\section{Th, -ASSOCIATED CYTOKINES}

IFN- $\gamma$ serum concentration in all our patients corresponded to the reference values. However, IFN- $\gamma$ levels in the children suffering from acute bronchitis with wheezing were lower than these levels in the children suffering from acute bronchitis without respiratory disorders had $(0.98 \pm 0.18$ $\mathrm{pg} / \mathrm{ml}$ and $2.17 \pm 0.55 \mathrm{pg} / \mathrm{ml}$, respectively; $\mathrm{p}<0.05$ ). IL-12 serum concentration in the children suffering from acute bronchitis with wheezing did not overstep the limits of the reference values and was significantly lower compared with the same parameter in the children suffering from acute bronchitis without respiratory disorders $(144.73 \pm 10.30$ $\mathrm{pg} / \mathrm{ml}$ and $249.00 \pm 15.87 \mathrm{pg} / \mathrm{ml}$, respectively; $\mathrm{p}<0.001$ ). It should be noted that IL-12 level in the patients suffering from acute bronchitis without wheezing was 1.5 times higher than its reference values (table 2).

According to our data, the maximum risk of the development of bronchial obstruction during acute bronchitis was observed among the children with IL-12 serum concentration from $41.35 \mathrm{pg} / \mathrm{ml}$ to $173.06 \mathrm{pg} / \mathrm{ml}(\mathrm{RR}=5.35$, $95 \% \mathrm{CI}=2.82-9.15)$. The probability of the appearance of wheezing was significantly reduced when IFN- $\gamma$ level was above $9.83 \mathrm{pg} / \mathrm{ml}(\mathrm{RR}=0.50,95 \% \mathrm{CI}=0.31-0.81), \mathrm{IL}-12$ level was above $173.06 \mathrm{pg} / \mathrm{ml}(\mathrm{RR}=0.49,95 \% \mathrm{CI}=0.30$ 0.82 ).

The obtained results confirm the opinion of scientists about the failure of the $\mathrm{Th}_{1}$-associated immune response in children suffering from acute bronchitis with wheezing. Relatively low $\mathrm{Th}_{1}$-associated cytokines serum concentration and, as a consequence, the formation of $\mathrm{Th}_{2}$-associated immune response determine the nature and severity of the 
Table 1. NF-kB expression level in infants with acute bronchitis

\begin{tabular}{ccc} 
Parameter & $\begin{array}{c}\text { Children suffering from acute bronchitis } \\
\text { with wheezing, } \mathbf{n = 8 0} \\
(\mathbf{M} \pm \mathbf{m})\end{array}$ & $\begin{array}{c}\text { Children suffering from acute bronchitis } \\
\text { without wheezing, } \mathbf{n = 4 0} \\
(\mathbf{M} \pm \mathbf{m})\end{array}$ \\
\hline $\begin{array}{c}\text { Lymphocytes expressing } \\
\mathbf{N F}-\boldsymbol{K} \boldsymbol{B}, \boldsymbol{\%}\end{array}$ & $39.69 \pm 1.44$ & $46.12 \pm 2.19$ \\
\hline NF-KB, Units & $0.71 \pm 0.02$ & $0.70 \pm 0.03$ \\
\hline
\end{tabular}

Table 2. The serum levels of $\mathrm{Th}_{1}$-associated cytokines in infants with acute bronchitis

\begin{tabular}{cccc}
\hline Parameter & $\begin{array}{c}\text { Children suffering from acute bronchitis } \\
\text { with wheezing, } \mathbf{n = 8 0} \\
(\mathbf{M} \pm \mathbf{m})\end{array}$ & $\begin{array}{c}\text { Children suffering from acute bronchitis } \\
\text { without wheezing, } \mathbf{n = 4 0} \\
(\mathbf{M} \pm \mathbf{m})\end{array}$ & Reference value \\
\hline IF $\mathbf{-} \boldsymbol{y}, \mathbf{p g} / \mathbf{m I}$ & $0.98 \pm 0.18^{* *}$ & $2.17 \pm 0.55$ & $0-188.9$ \\
\hline IL-12, $\mathbf{p g} / \mathbf{m I}$ & $144.73 \pm 10.30^{* *}$ & $249.00 \pm 15.87^{*}$ & $40.4-150$ \\
\hline
\end{tabular}

Note: ${ }^{*} p \leq 0.05$ - significant difference from the reference value of the parameter

** $p \leq 0.05$ - significant difference from the parameter value in children of another group

Table 3. The serum levels of $\mathrm{Th}_{2}$-associated cytokines and total lgE in infants with acute bronchitis

\begin{tabular}{|c|c|c|c|}
\hline Parameter & $\begin{array}{l}\text { Children suffering from acute bronchitis } \\
\text { with wheezing, } \mathrm{n}=\mathbf{8 0} \\
\qquad(\mathrm{M} \pm \mathrm{m})\end{array}$ & 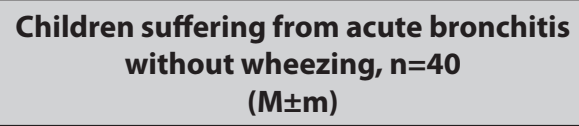 & $\begin{array}{c}\text { Reference } \\
\text { value }\end{array}$ \\
\hline IL-4, pg/mI & $1.79 \pm 0.08$ & $1.88 \pm 0.08$ & $0-4$ \\
\hline IL-13, pg/mI & $4.15 \pm 0.19$ & $4.86 \pm 0.43$ & $0-44.4$ \\
\hline \multirow{3}{*}{$\begin{array}{l}\qquad \mathbf{I g E}, \mathbf{I U} / \mathbf{m l} \\
\text { - children aged from } \\
6 \text { to } 12 \text { months; } \\
\text { - children aged from } \\
1 \text { to } 3 \text { years old }\end{array}$} & $87.09 \pm 11.37 * *$ & $52.37 \pm 9.57$ & \\
\hline & $39.84 \pm 5.2^{* * * *}$ & $17.94 \pm 2.13$ & $\leq 15$ \\
\hline & $134.34 \pm 19.54 * * * *$ & $65.42 \pm 12.37$ & $\leq 60$ \\
\hline
\end{tabular}

Note: ${ }^{*} p \leq 0.05$ - significant difference from the reference value of the parameter

${ }^{* *} p \leq 0.05$ - significant difference from the parameter value in children of another group

inflammatory process underlying in the development of bronchial obstruction [21-25].

\section{$\mathrm{Th}_{2}$-ASSOCIATED CYTOKINES AND TOTAL IgE}

The serum concentrations of IL-4 and IL-13 in the examined children corresponded to the reference values and did not depend on the course of acute bronchitis. Respectively, their levels reached $1.79 \pm 0.08 \mathrm{pg} / \mathrm{ml}$ and $4.15 \pm 0.19 \mathrm{pg} /$ $\mathrm{ml}$ in the children suffering from acute bronchitis with wheezing, $1.88 \pm 0.08 \mathrm{pg} / \mathrm{ml}$ and $4.86 \pm 0.43 \mathrm{pg} / \mathrm{ml}$ in the children suffering from acute bronchitis without respiratory disorders (table 3 ).

It should be noted that $60 \%$ of the children suffering from acute bronchitis with wheezing and 55\% of the children suffering from acute bronchitis without respiratory disorders ( $p>0.05$ ) had high serum concentration of total IgE. Moreover, every second patient with high IgE level was a child of the first year of life. Perhaps the reasons for that are the physiological features of the immune system, which determine significant rise in the sensitivity of infants to both infectious environmental factors and allergen exposure [22, 25].

The average serum concentration of total IgE in the children suffering from acute bronchitis with wheezing was significantly higher than in the children suffering from acute bronchitis without respiratory disorders (Table 3). Total IgE level reached $87.09 \pm 11.37 \mathrm{IU} / \mathrm{ml}$ and $52.37 \pm 9.57 \mathrm{IU} / \mathrm{ml}$, respectively $(\mathrm{p}<0.05)$.

The highest risk of the development of bronchial obstruction during acute bronchitis in the infants was associated with IL-13 concentration from $4.06 \mathrm{pg} / \mathrm{ml}$ to $6.71 \mathrm{pg} / \mathrm{ml}$ $(\mathrm{RR}=4.0,95 \% \mathrm{CI}=2.39-6.41)$. At the same time the level of this anti-inflammatory cytokine above $6.71 \mathrm{pg} / \mathrm{ml}$ prevented the children from the development of bronchial obstruction $(\mathrm{RR}=0.40,95 \% \mathrm{CI}=0.22-0.72)$. We think that it may be due to IL-13 inhibitory effect on the activity of the main transcriptional inflammatory factor NF- $\kappa \mathrm{B}[26]$.

\section{CONCLUSIONS}

1. NF- $\kappa \mathrm{B}$ expression level predetermines the activity of cytokine production and, as a consequence, the course of acute bronchitis in infants.

2. Relatively low NF- $\kappa \mathrm{B}$ and IL-12 levels are early predictors of the bronchial obstruction development.

3. The relatively high activity of $N F-\kappa B$ transcription factor and increased IL-12 production at the onset of the acute bronchitis considerably reduce the risk of the development of bronchial obstruction. 
4. The development of bronchial obstruction during acute bronchitis in infants is associated with imbalance in IFN- $\gamma$ and IL-13 production.

\section{REFERENCES}

1. Ministry of Health of Ukraine, GA "Ukrainian Institute of Strategic Studies". 2017 Annual report on the state of health of the population, the sanitary-epidemic situation and the results of the health care system of Ukraine. Kyiv: IEC "Medinform". 2018. 458 pp. [Ukrainian].

2. Maydannik VG, Yemchinskaya EA. Clinical recommendations for the diagnosis and treatment of acute bronchitis in children from the position of evidence-based medicine. Kiev. 2014. 56 pp. [Russian].

3. Lapshin VF, Umanets TR, Pustovalova OI. Acute obstructive bronchitis in children: the efficacy and tolerability of Prospan drops and syrup. Child's Health. 2018;8(13):33-38. (Ukrainian).

4. Bessa $0 A$, Leite AJ, Solé D, Mallol J. Prevalence and risk factors associated with wheezing in the first year of life. J. Pediatr. (Rio J.). 2014 MarApr;90(2):190-6. doi: 10.1016/j.jped.2013.08.007.

5. Soloveva NA, llenkova NA, Smirnova SV. Bronchial obstructive syndrome in infants. RussianPediatric Journal (RossiiskiiPediatricheskiiZhurnal). 2014;4:32-38. (Russian).

6. Volosovec AP, Krivopustov SP, Vezhnovets El. Risk factors for the development of recurrent bronchial obstructive syndrome which is induced by viruses in children. XVI Congress of the SFULT, August 18-23, 2016: Materials. Kyiv; Berlin. 2016. P. 41. (Ukrainian).

7. Pacheco-Gonzalez RM, Mallol J, Solé D, Brand PL, Perez-Fernandez V, Sanchez-Solis M, Garcia-Marcos L. Factors associated with the time to the first wheezing episode in infants: a cross-sectional study from the International Study of Wheezing in Infants (EISL). NPJ Prim. Care Respir. Med. 2016 Jan 21;26:15077. doi: 10.1038/npjpcrm.2015.77.

8. Garcia-Marcos I, Mallol J, Solé D, Brand PL. International study of wheezing in infants: risk factors in affluent and non-affluent countries during the first year of life. Pediatr. Allergy Immunol. 2010 Aug;21(5):878-88. doi: 10.1111/j.1399-3038.2010.01035.x.

9. Caudri D, Savenije OE, Smit HA, Postma DS, Koppelman GH, Wijga AH, Kerkhof M, Gehring U, Hoekstra M0, Brunekreef B, de Jongste JC. Perinatal risk factors for wheezing phenotypes in the first 8 years of life. Clin. Exp. Allergy. 2013 Dec;43(12):1395-405. doi: 10.1111/cea.12173.

10. Taylor-Robinson DC, Pearce A, Whitehead M, Smyth R, Law C. Social inequalities in wheezing in children: findings from the UK Millennium Cohort Study. Eur. Respir. J. 2016 Mar;47(3):818-828. doi: 10.1183/13993003.01117-2015.

11. Okhotnikova EN. Airway obstruction syndrome in children: the difficult questions - the right decisions. Child's Health. 2016;1(69):88-96. (Russian).

12. El-Gamal YM, El-Sayed SS. Wheezing in infancy. World Allergy Organ. J. 2011 May;4(5):85-90. doi: 10.1097/WOX.0b013e318216b41f.

13. Martinez FD, Wright AL, Taussig LM, Holberg CJ, Halonen M, Morgan WJ. Asthma and wheezing in the first six years of life. The Group Health Medical Associates. N. Engl. J. Med. 1995 Jan 19;332(3):133-8.

14. Kovalenko TS. The clinical characteristics of toddlers suffering from acute obstructivebronchitis Ukrainian medical almanac. 2012;15(6):79-83. (Ukrainian).

15. Burke H, Leonardi-Bee J, Hashim A, Pine-Abata H, Chen Y, Cook DG, Britton JR, McKeever TM. Prenatal and Passive Smoke Exposure and Incidence of Asthma and Wheeze: Systematic Review and Meta-analysis. Pediatrics. 2012 Apr;129(4):735-44. doi: 10.1542/peds.2011-2196.

16. Been JV, Lugtenberg MJ, Smets $E$, van Schayck CP, Kramer BW, Mommers M, Sheikh A. Preterm birth and childhood wheezing disorders: a systematic review and meta-analysis. PLoS Med. 2014 Jan 28;11(1):e1001596. doi: 10.1371/journal.pmed.1001596.
17. Moraes S, Takano OA, Mallol J, Solé D. Risk factors associated with wheezing in infants. J. Pediatr. (Rio J.). 2013 Nov-Dec;89(6):559-66. doi: 10.1016/j.jped.2013.04.004.

18. Wullaert A, Bonnet MC, Pasparakis M. NF-kB in the regulation of epithelial homeostasis and inflammation. Cell. Res. - 2011 Jan;21(1):146-58. doi: 10.1038/cr.2010.175.

19. Vallabhapurapu S, Karin M. Regulation and function of NF-kappaB transcription factors in the immune system. Annu Rev. Immunol. 2009;27:693-733. doi: 10.1146/annurev.immunol.021908.132641.

20. Liang Y, Zhou Y, Shen P. NF-kB and it's regulation on the immune system. Cell. Mol. Immunol. 2004 0ct;1(5):343-50.

21. Bezrukova LA, Starikovich MV, Belan YuB. Possibilities of early immunocorrection of bronchial obstructive conditions in children with burdened allergological anamnesis. Lechaschii Vrach Journal. 2011;6:12-15. (Russian).

22. Tregoning JS, Schwarze J. Respiratory Viral Infections in Infants: Causes, Clinical Symptoms, Virology, and Immunology. Clin. Microbiol. Rev. 2010 Jan;23(1):74-98. doi: 10.1128/CMR.00032-09.

23. Abaturov AE, Yulish El. The role of interferon in the protection of the respiratory tract. Part 1. Cascade of interferon system excitation. Child's Health. 2007;5(8):136-144. [Russian].

24. Abaturov AE, Yulish El. The role of interferon in the protection of the respiratory tract. Mechanisms of action of interferons. Child's Health. 2007;6(9):111-118. (Russian).

25. Kushnareva MV, Vinogradova TV, Keshishian ES, Parfenov VV, Koltsov VD, Bragina GS, Parshina OV, Guseva TS. Specific features of the immune status and interferon system of infants. Rossiyskiy Vestnik Perinatologii i Pediatrii (Russian Bulletin of Perinatology and Pediatrics). 2016;61(3):12-21. doi: 10.21508/1027-4065-2016-61-3-12-21. (Russian).

26. Abaturov AE, Volosovec AP, Yulish El. Induction of molecular mechanisms of nonspecific respiratory tract protection. Kiev: Privatna drukarnya F0-P Storozhuk OV. 2012. 240 pp. (Russian).

\section{ORCID and contributionship:}

Alexandr E. Abaturov - 0000-0001-6291-5386 A, C, D, E, F

Olena O. Rusakova - 0000-0002-5097-1185 B, C, D, E, F

\section{Conflicts of interest:}

Authors declare no conflict of interest.

\section{CORRESPONDING AUTHOR}

\section{Olena 0. Rusakova}

Department of Pediatrics 1 and Medical Genetics

State Institution “Dnipropetrovsk Medical Academy

of the Ministry of Health of Ukraine"

9, V. Vernadskogo Street, 49044, Dnipro, Ukraine

tel: +380975426535

e-mail: rusakova.elena78@gmail.com

Received: 08.05.2019

Accepted: 27.12 .2019

A - Work concept and design, B - Data collection and analysis, C - Responsibility for statistical analysis,

D-Writing the article, $\mathbf{E}$-Critical review, $\mathbf{F}$ - Final approval of the article 